\title{
Implementasi Web Programming Pada Sistem Seleksi Peserta Pelatihan Kerja
}

\author{
Yuyun Yuningsih ${ }^{1}$, Ari Puspita ${ }^{2}$
}

\begin{abstract}
In the selection process of training participants, most of them use conventional methods, namely the selection method, where from registration to graduation are still carried out by coming directly to the office. Of course, this is considered less effective in this era, because the process is complicated and takes a long time. With the e-recruitment or online selection process, companies can make cost savings, the organization's brand can be better known and increase the chances of getting prospective employees who meet the criteria (job specifications) that have been set by the organization. This study discusses the selection system for prospective trainees, where the selection activities are still manual. This system is designed to be able to process the selection data of prospective trainees such as the registration process, filling in the personal data of the prospective selection participants, managing test data, selection results and printing reports. By implementing an information system for the selection of prospective participants, it can minimize time and costs in the training participant selection process, Process information, selection, selection more quickly and efficiently and help get the best prospective participants in accordance with the required training position.
\end{abstract}

Intisari-Dalam proses seleksi peserta pelatihan, sebagian besar perusahaan masih menggunakan metode konvensional, yaitu metode seleksi manual, dimana dari mulai pendaftaran hingga pengumuman kelulusan masih dilakukan dengan cara datang langsung ke kantor. Tentunya hal tersebut dinilai kurang efektif di era ini, dikarenakan proses yang berbelit dan butuh waktu yang lama. Dengan adanya e-recruitmen atau proses seleksi secara online, perusahaan dapat melakukan penghematan biaya, brand organisasi dapat lebih dikenal dan memperbesar peluang mendapat calon karyawan yang sesuai kriteria (job specification) yang telah ditetapkan organisasi. Penelitian ini membahas tentang sistem seleksi calon peserta pelatihan kerja, dimana dalma kegiatan seleksi yang masih manual. Sistem ini dirancang untuk dapat mengolah data seleksi calon peserta pelatihan kerja seperti proses registrasi, mengisi data diri calon peserta seleksi, mengelola data test, data hasil seleksi dan mencetak laporan. Dengan menerapkan sistem informasi seleksi calon peserta maka dapat meminimalisir waktu dan biaya dalam proses seleksi peserta pelatihan kerjabaru, Pemrosesan informasi lowongan seleksi lebih cepat dan efisien dan Membantu mendapatkan calon peserta terbaik yang sesuai dengan posisi pelatihan yang dibutuhkan.

1 Sistem Informasi Universitas Nusa Mandiri,Jl. Jatiwaringin Raya No. 02, Jakarta Timur; Telp. (021) 28534471; email:yuyun.yyg@nusamandiri.ac.id

${ }^{2}$ Sistem Informasi Universitas Bina Sarana Informatika, Jl. Kramat No. 98 Jakarta Pusat; Telp. (021) 21231170 Indonesiaemail: ari.arp@bsi.ac.id
Kata Kunci : Sistem, Pengolahan Data, Seleksi Kerja

\section{Pendahuluan}

Di masa sekarang kemajuan ilmu dan teknologi telah mendorong terjadinya perubahan pada semua bidang, salah satunya adalah kegiatan dalam bekerja.

Implementasi teknologi dalam kehidupan sangat membantu mempersingkat waktu dalam mengerjakan suatu hal. Salah satu contoh implementasinya adalah proses seleksi kerja atau pelatihan secara online. [1]

Pengelolaan informasi yang cepat dan akurat menjadi sangat penting, karena dapat membantu perkembangan sebuah lembaga maupun instansi. Salah satu bentuk implementasi sistem informasi yang cepat, tepat dan akurat ini adalah sistem informasi berbasis web programming, dimana Sistem informasi ini memanfaatkan sebuah teknologi komputer [2]

Namun pada kenyataannya masih banyak perusahaan/lembaga yang masih menggunakan sistem yang belum terkomputerisasi.[3]

Seleksi atau perekrutan adalah "sebuah langkah awal pelaksanaan rencana kepegawaian yang bertujuan untuk memperoleh tenaga kerja yang potensial dan berkualitas. [4]

Dalam proses seleksi peserta pelatihan, sebagian besar perusahaan masih menggunakan metode konvensional, yaitu metode seleksi manual, dimana dari mulai pendaftaran hingga pengumuman kelulusan masih dilakukan dengan cara datang langsung ke kantor. Tentunya hal tersebut dinilai kurang efektif di era ini, dikarenakan proses yang berbelit dan butuh waktu yang lama

Dengan adanya e-recruitmen atau proses seleksi secara online, perusahaan dapat melakukan penghematan biaya, brand organisasi dapat lebih dikenal dan memperbesar peluang mendapat calon karyawan yang sesuai kriteria (job specification) yang telah ditetapkan organisasi.[5]

Permasalahan-permasalahan yang sering timbul dalam sistem seleksi peserta pelatihan kerja ini adalah:

1. Lamanya proses seleksi peserta pelatihan kerjamulai dari pendaftaran hingga pengumuman kelulusan.

2. Pelaksanaan pendaftarann hingga test seleksi peserta pelatihan kerja ini masih menggunakan metode manual, 
yaitu menggunakan kertas, sehingga proses pendataan dan seleksi berlangsung lama.

3. penyimpanan data calon peserta pelatihan kerja yang tidak tersusun rapi dan terselip/hilang

Dari latar belakang diatas, maka tujuan dari penelitian ini adalah:

1. Mempermudah pihak calon peserta pelatihan kerja dalam mendapatkan informasi seputar pelatihan kerja.

2. Mempermudah pegawai dalam menjalankan proses seleksi calon peserta pelatihan kerja.

3. Data peserta tersimpan dengan rapi dan meminimalisir kehilangan data

\section{METODOLOGI PENELITIAN}

A. Jenis Penelitian

Jenis Penelitian yang dibuat oleh penulis ada penelitian Kuantitatif. [6]

B. Waktu dan Tempat Penelitian

Waktu yang dibutuhkan peneliti dari mulai Analisa kebutuhan Sistem, desain, Pembuatan Kode program, Testing dan Support dilakukan peneliti pada bulan Maret s.d Mei 2021.

C. Tahapan Penelitian

Pada Bab ini penulis akan menjelaskan mengenai langkah-langkah dalam melakukan penelitian yaitu sebagai berikut :

1. Analisa Kebutuhan Sistem

Berdasarkan penelitian yang telah dilakukan, untuk menspesifikasikan kebutuhan perangkat lunak agar dapat dipahami dan sesuai dengan apa yang dibutuhkan oleh user, maka analisa kebutuhan sistem yang akan dibangun adalah sistem rekrutmen peserta pelatihan [7]

2. Tahapan Desain

Penulis mendesain perangkat lunak, dengan menggunakan peralatan pendukung yang digunakan untuk menggambarkan bentuk logika model dari suatu sistem dengan menggunakan simbol-simbol, lambanglambang, diagram-diagram yang menunjukan secara tepat arti dan fungsinya antara lain UML (Unifield Modelling Language) yang mencakup Activity diagram, Use Case diagram, Entity Relationship Diagram (ERD), Logical Record Structure (LRS), Sequence diagram, Deployment diagram.[8]

\section{Pembuatan Kode Program}

Penulis menggunakan XAMPP sebagai server yang mudah digunakan yang dapat melayani tampilan halaman aplikasi yang dinamis, penulis juga menggunakan bahasa pemrograman HTML, CSS, PHP dan Javascript.[9]

\section{Tahapan Pengujian (Testing)}

Dalam pengujian ini penulis menggunakan metode blackbox testing dengan memberikan masukanmasukan kepada sistem atau program yang telah dibuat, apakah keluaran dari program yang telah dibuat sesuai dengan apa yang diharapkan atau tidak. Pengujian ini dilakukan untuk meminimalisir suatu kesalahan dan memastikan keluaran dari program telah sesuai dengan yang diharapkan oleh user.

\section{Support}

pada tahap ini penulis akan memelihara sistem, memperbaiki kesalahan dan mengembangkan sistem untuk meningkatkan kemampuan sistem yang lebih besar serta mendukung pengguna selama menggunakan aplikasi.[10]

\section{Data, Instrumen dan Teknik Pengumpulan data}

Metode pengumpulan data adalah faktor yang sangat penting dalam proses keberhasilan pada suatu penelitian. Karena hal ini berkaitan dengan bagaimana cara mengumpulkan data dan siapa sumber yang memberikan informasi data yang dapat digunakan dalam proses penelitian tersebut[11]:

\section{a. Observasi}

Penulis melakukan pengamatan secara langsung pada Lembaga/instansi yang berhubungan dengan penelitian penulis. Pengamatan dilakukan pada bagian pembelian untuk memperoleh sejumlah data mengenai kegiatan pembelian secara tunai.

\section{b. Studi pustaka}

Pada penelitian ini penulis melakukan kajian pada jurnal-jurnal dari peneliti-peneliti sebelumnya, dan sumber-sumber atau bahan lainnya yang berhubungan dengan tema penelitian yang penulis ambil untuk dijadikan sebagai bahan referensi dan acuan dalam melakukan penelitian ini.

\section{HASIL DAN PEMBAHASAN}

\section{A. Analisa Kebutuhan Sistem}

Analisa ini merupakan awal dari langkah yang akan dilakukan dalam proses mengembangkan atau membuat sebuah sistem aplikasi, dengan cara menganalisa kebutuhan-kebutuhan apa saja yang akan dijadikan sebagai bahan masukan dalam pembuatan aplikasi tersebut. Dengan mengetahui bahan masukan yang diperlukan dan keluaran yang diinginkan maka diharapkan aplikasi yang dibuat akan mudah digunakan dan mudah dipahami oleh penggunanya.

Analisa kebutuhan pengguna untuk sistem seleksi calon peserta pelatihan kerja diusulkan dengan beberapa prosedur antara lain:

1. Halaman Calon Peserta

a. Calon Peserta dapat melakukan registrasi online

b. Calon Peserta dapat melakukan login

c. Calon Peserta dapat mengisi form data diri

d. Calon Peserta dapat memilih pelatihan

e. Calon Peserta dapat mengikuti seleksi pelatihan 


\section{JURNAL SISTEM INFORMASI}

STMIK ANTAR BANGSA

2. Halaman Petugas

a. Petugas dapat melakukan login

b. Petugas dapat mengelola data lowongan pelatihan

c. Petugas dapat mengelola data calon peserta

d. Petugas dapat mengelola data seleksi

e. Petugas dapat mengelola data hasil seleksi dengan metode profile matching

f. Petugas dapat mencetak laporan

\section{B. Use Case Diagram}

1. Use case diagram calon peserta pada aplikasi sistem seleksi calon peserta pelatihan kerja dapat dilihat pada gambar 1 sebagai berikut:

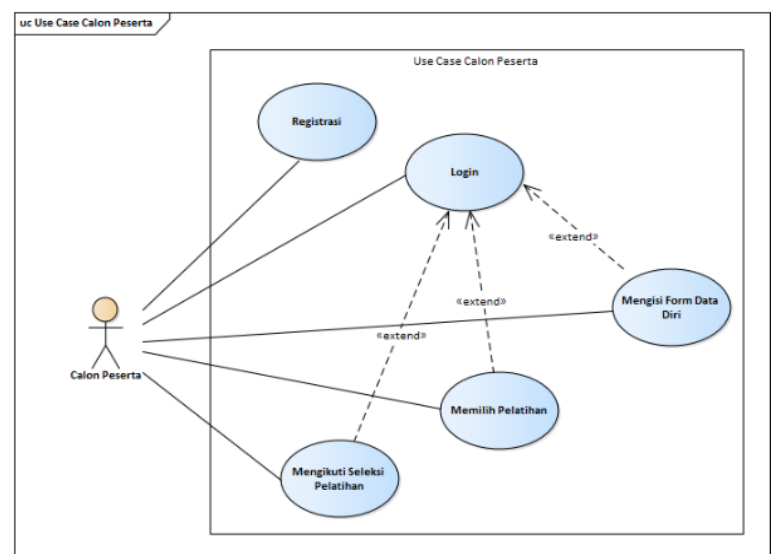

Gambar 1. Use Case Diagram Calon Peserta

2. Use case diagram Petugas pada aplikasi sistem seleksi calon peserta pelatihan kerja dapat dilihat pada gambar 2 sebagai berikut:

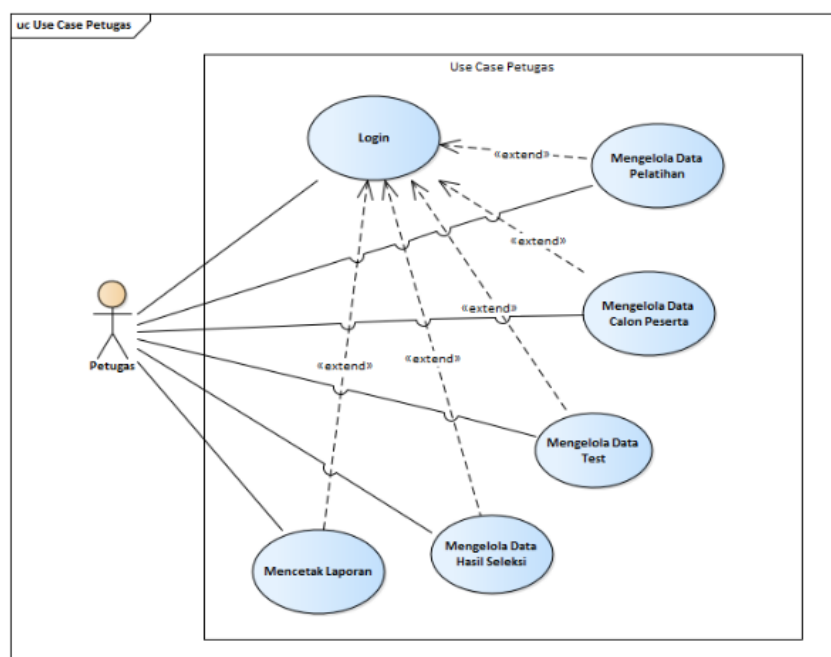

Gambar 2. Use Case Diagram Petugas

C. Activity Diagram

1. Activity Diagram Halaman Calon Peserta a) Activity Diagram Registrasi

Activity Diagram Registrasi dapat dilihat pada gambar 3 berikut:

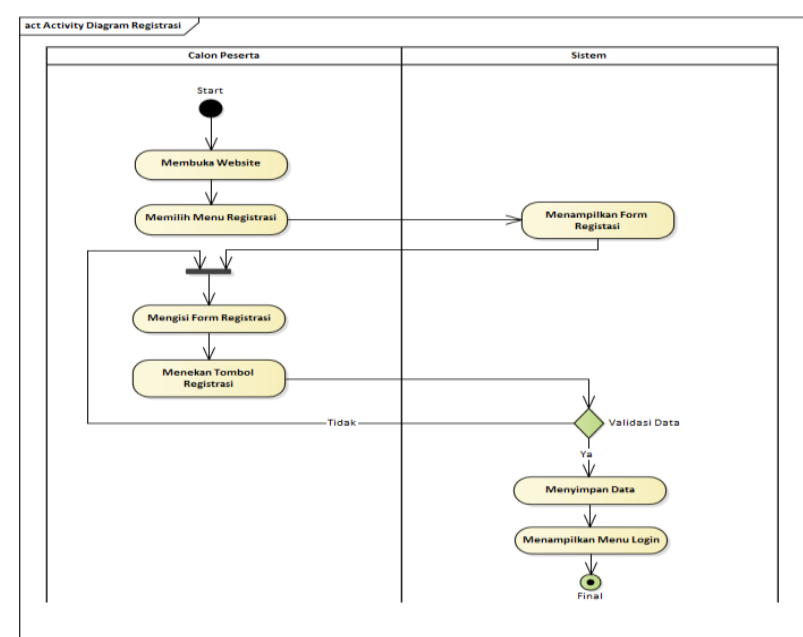

Gambar 3. Activity Diagram Registrasi

\section{b) Activity Diagram Login}

Activity Diagram login dapat dilihat pada gambar 4 berikut:

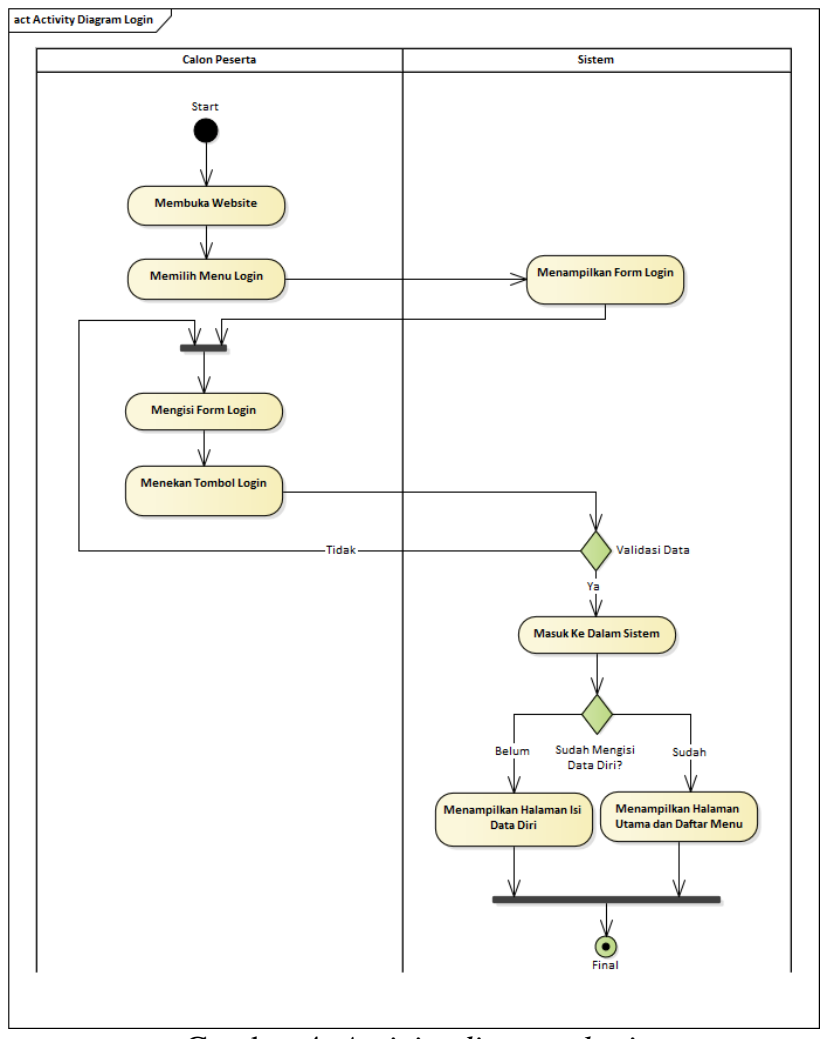

Gambar 4. Activity diagram login

c) Activity Diagram Mengisi Data Diri

Activity diagram Mengisi Data Diri dapat dilihat pada gambar 5 berikut: 


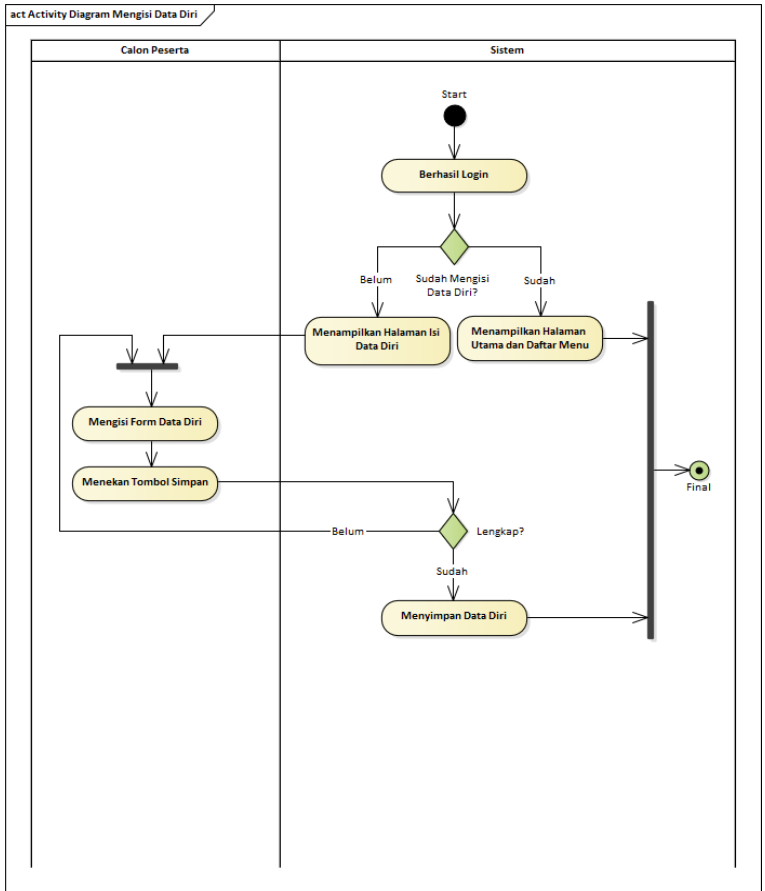

Gambar 5. Activity diagram Mengisi Data Diri

d) Activity Diagram Memilih Pelatihan

Activity Diagram Memilih Pelatihan dapat dilihat pada gambar 6 berikut:

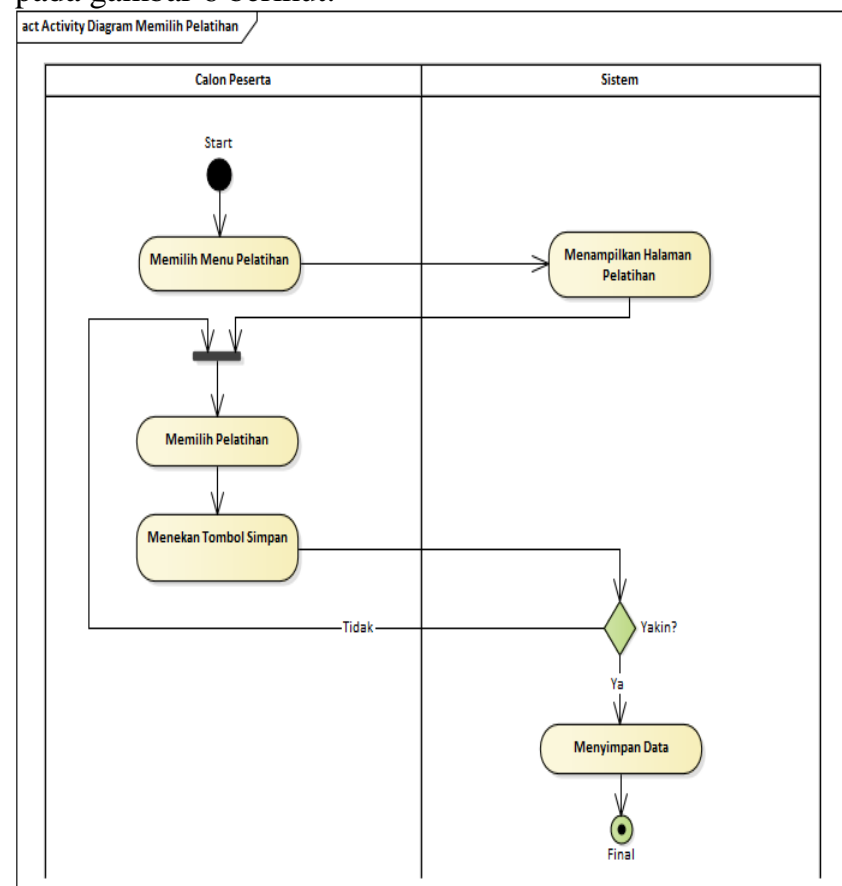

Gambar 6. Activity Diagram Memilih Pelatihan

\section{e) Activity Diagram Mengikuti Seleksi Pelatihan} Tahap Satu

Activity Diagram Mengikuti Seleksi Pelatihan Tahap

Satu dapat dilihat pada gambar 7 berikut:

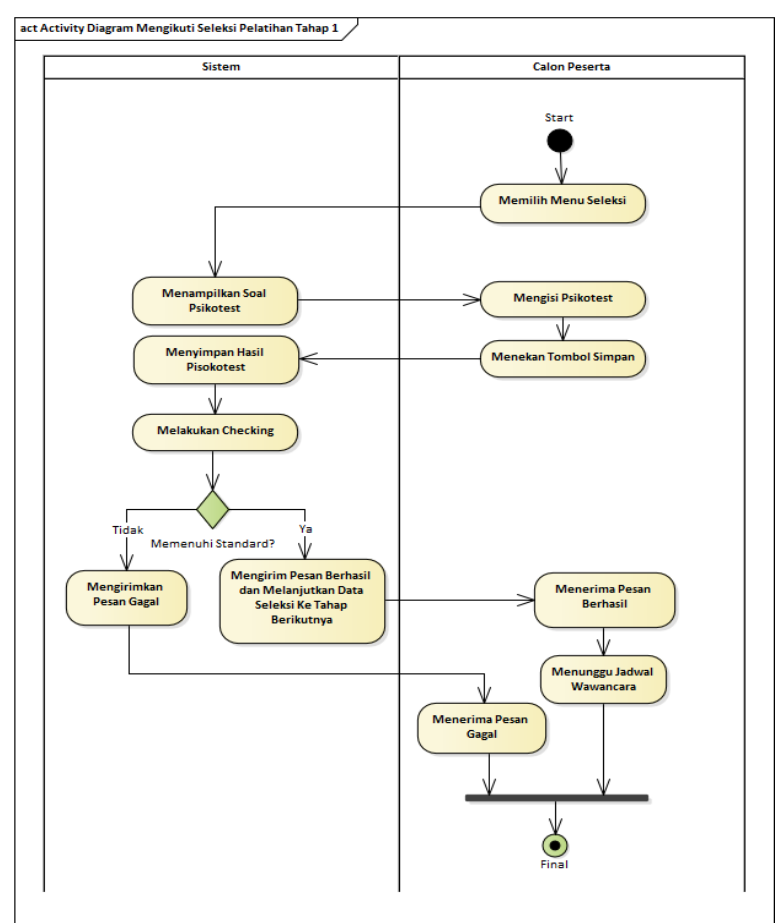

Gambar 7. Activity Diagram Mengikuti Seleksi Pelatihan Tahap Satu

\section{f) Activity Diagram Mengikuti Seleksi Pelatihan Tahap Dua}

Activity Diagram Mengikuti Seleksi Pelatihan Tahap Dua dapat dilihat pada gambar 8 berikut:

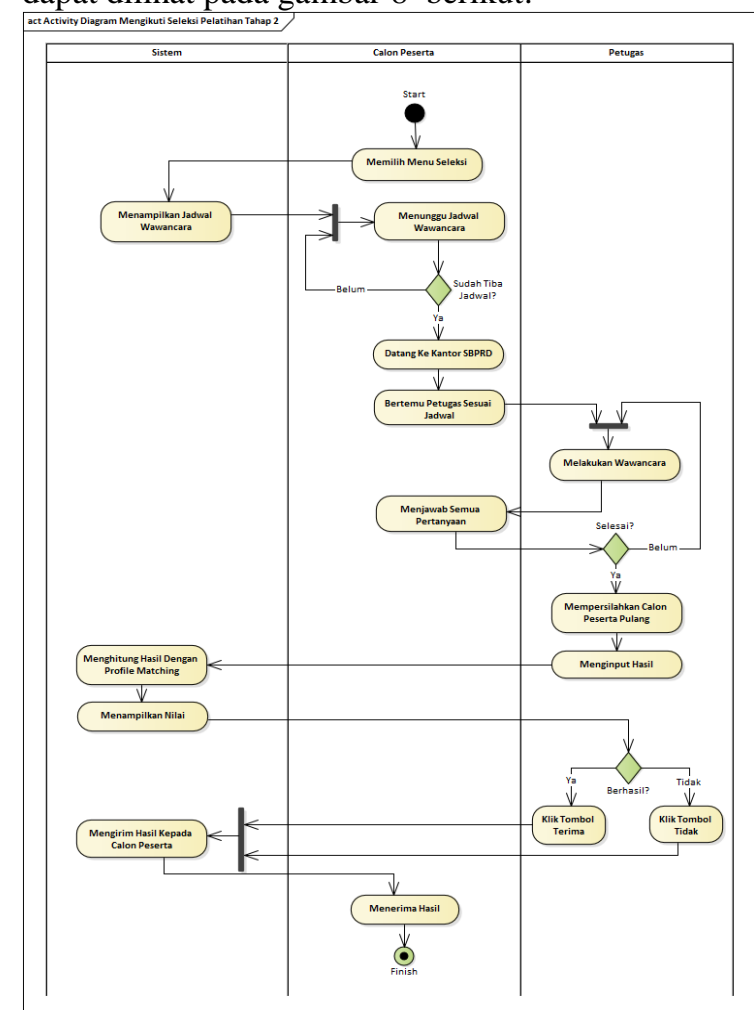

Gambar 8. Activity Diagram Mengikuti Seleksi Pelatihan Tahap Dua 


\section{JURNAL SISTEM INFORMASI}

STMIK ANTAR BANGSA

[VOL. X NO. 2 AGUSTUS 2021]

\section{Activity Diagram Halaman Petugas}

a) Activity Diagram Login

Activity Diagram Login dapat dilihat pada gambar 9 berikut:

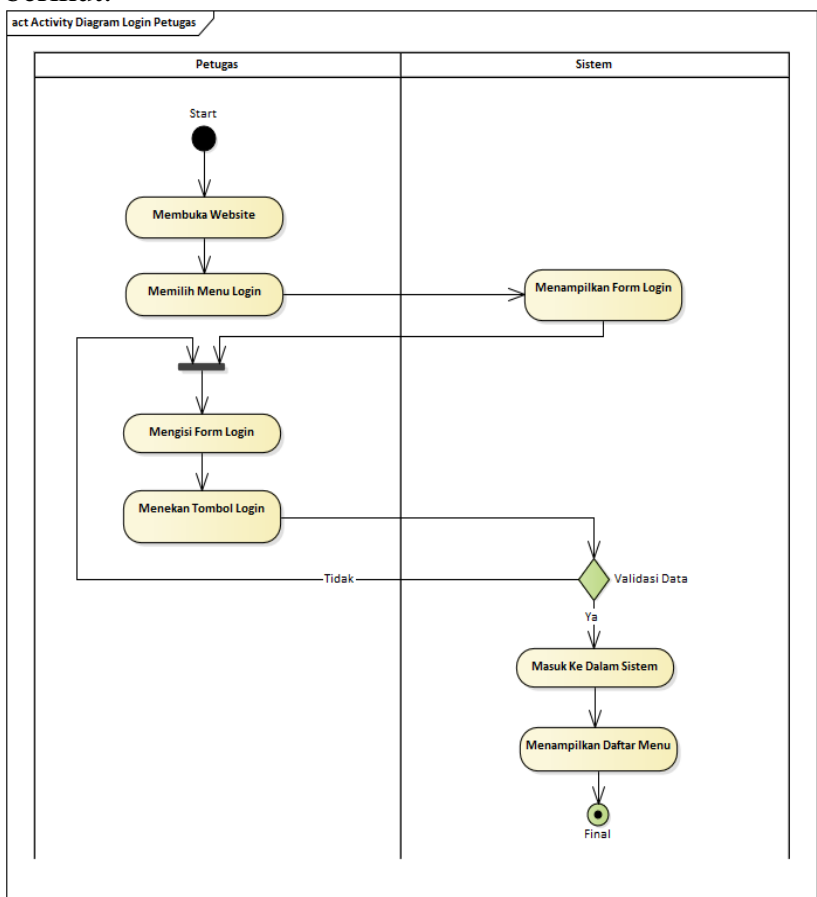

Gambar 9. Activity Diagram Login

\section{b) Activity Diagram Mengelola Data Pelatihan} Activity Diagram Mengelola Data Pelatihan dapat dilihat pada gambar 10 berikut:

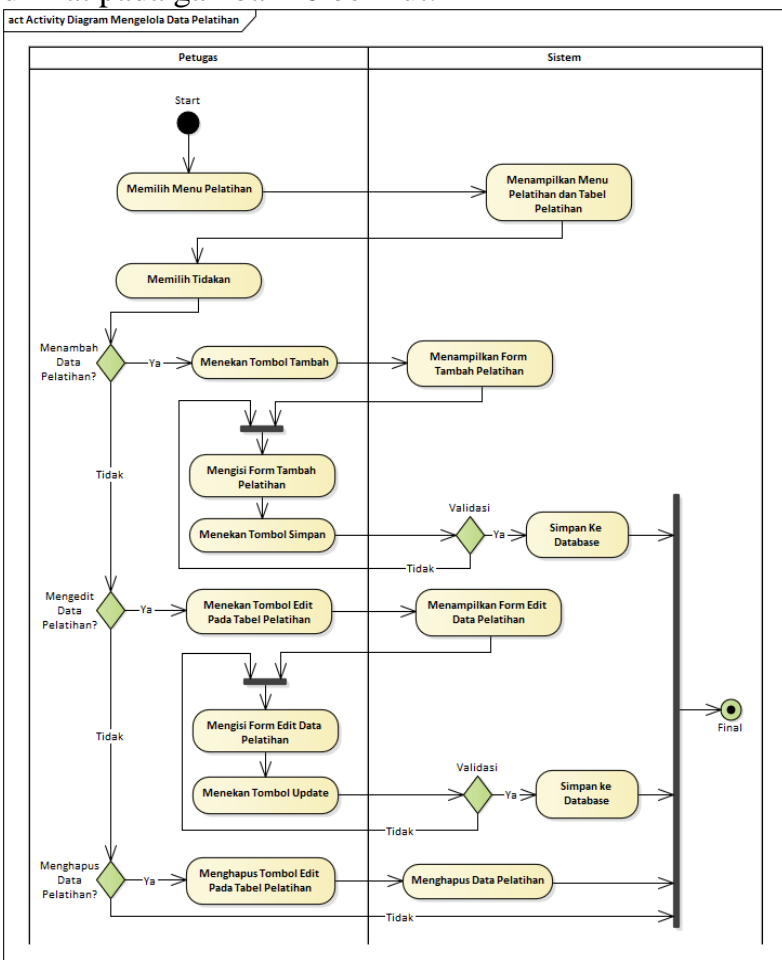

Gambar 10. Activity Diagram Mengelola Data Pelatihan c) Activity Diagram Mengelola Data Calon Peserta Activity Diagram Mengelola Data Calon Peserta dapat dilihat pada gambar 11 berikut:

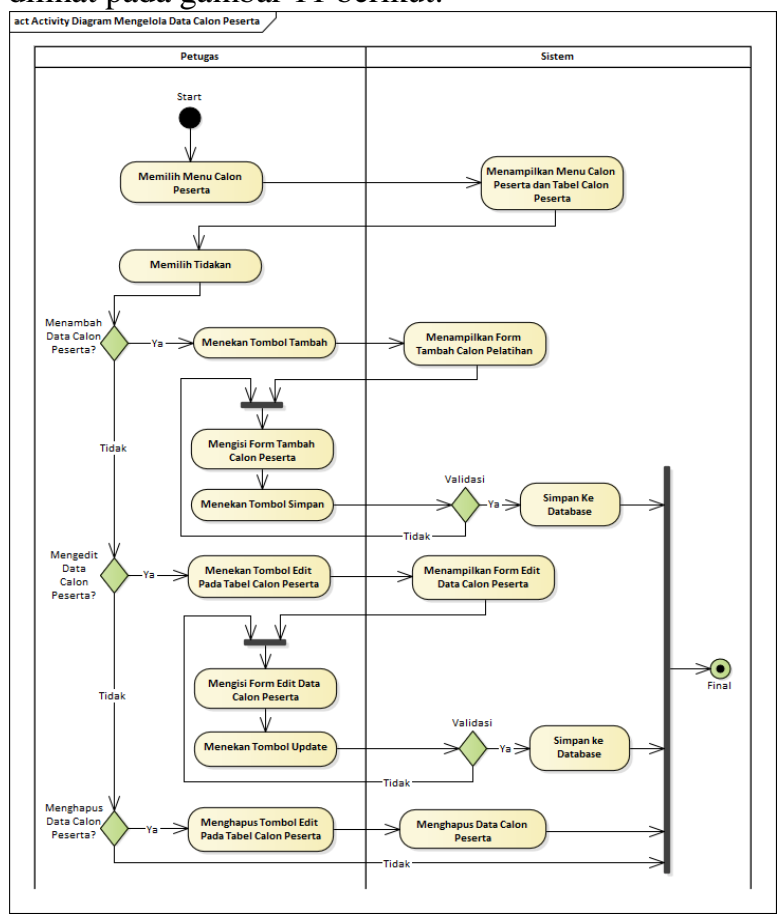

Gambar 11. Activity Diagram Mengelola Data Calon Peserta

d) Activity Diagram Mengelola Data Test

Activity Diagram Mengelola Data Test dapat dilihat pada gambar 12 berikut:

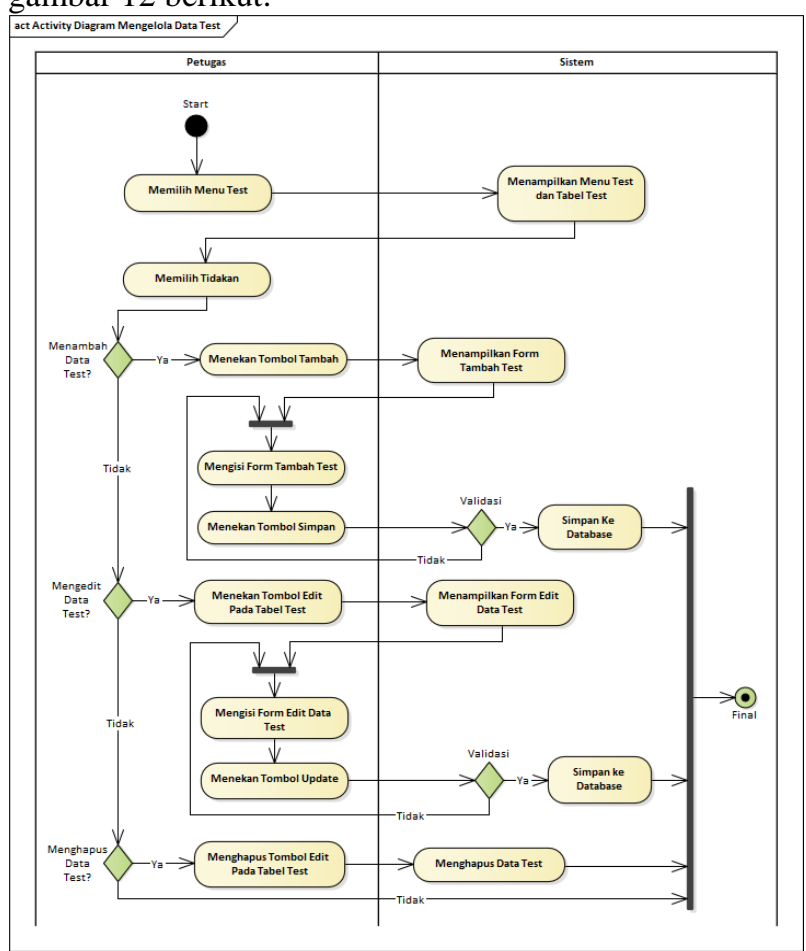

Gambar 12. Activity Diagram Mengelola Data Test 
e) Activity Diagram Mengelola Data Hasil Seleksi Activity Diagram Mengelola Data Hasil Seleksi dapat dilihat pada gambar 13 berikut:

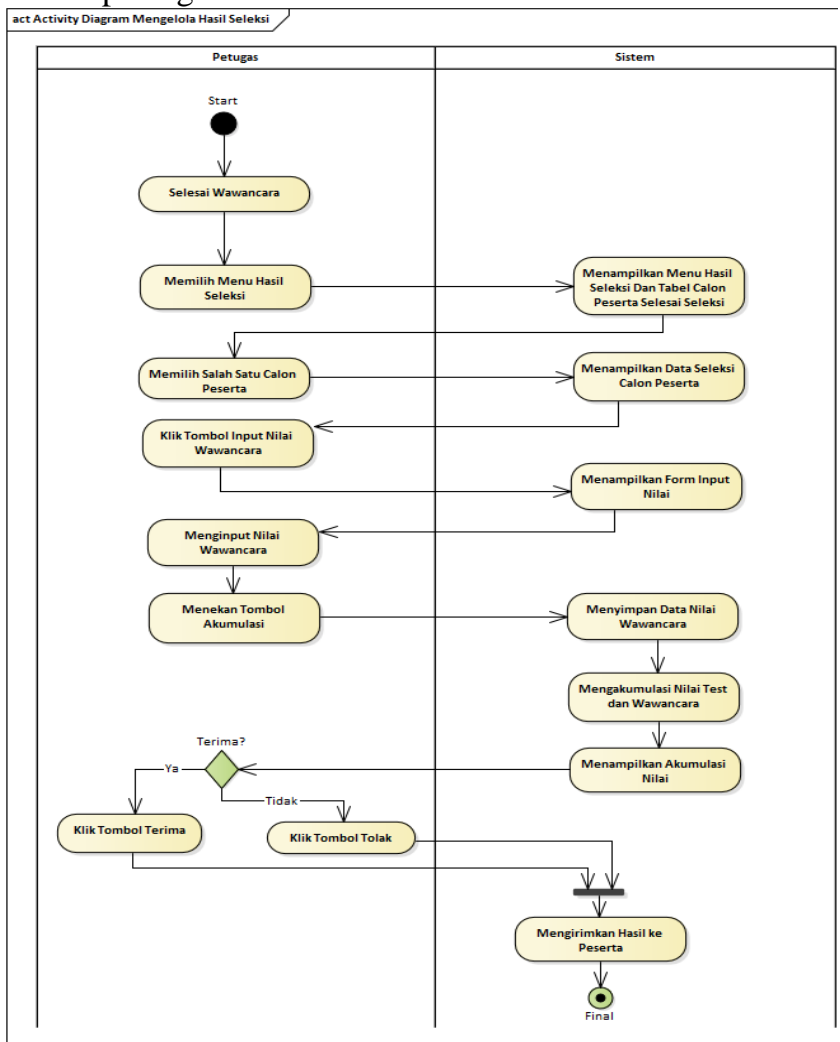

Gambar 13. Activity Diagram Mengelola Data Hasil Seleksi

\section{f) Activity Diagram Mencetak Laporan}

Activity Diagram Mencetak Laporan dapat dilihat gambar 14 berikut:

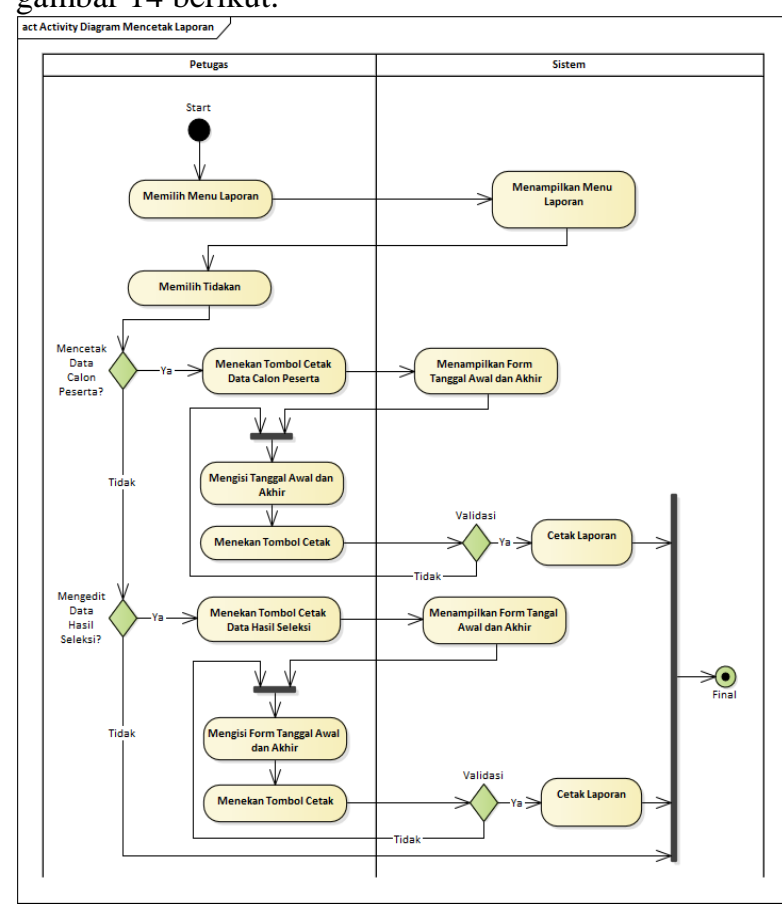

Gambar 14. Activity Diagram Mencetak Laporan
3. Logical Data Model

Logical Data Model dapat dilihat pada gambar 15 berikut:

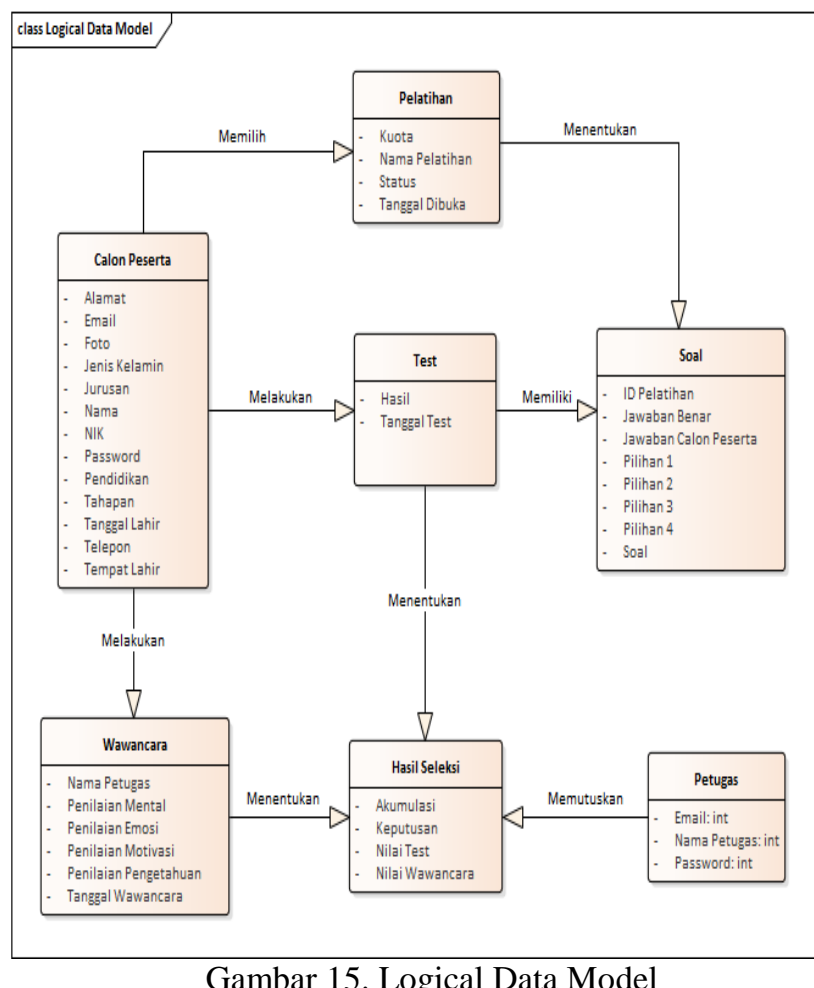

4. Class Diagram

Class diagram dapat dilihat pada gambar 16 berikut:

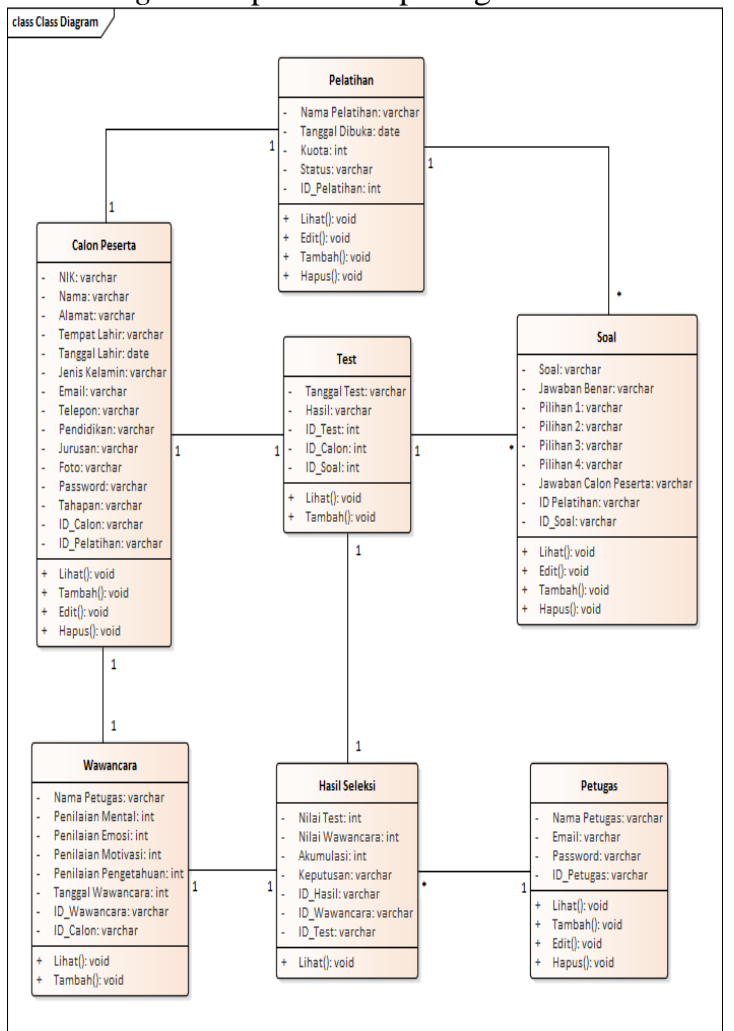

Gambar 16. Class Diagram 


\section{JURNAL SISTEM INFORMASI}

STMIK ANTAR BANGSA

\section{Deployment Diagram}

Deployment Diagram dapat dilihat pada gambar 17 berikut:

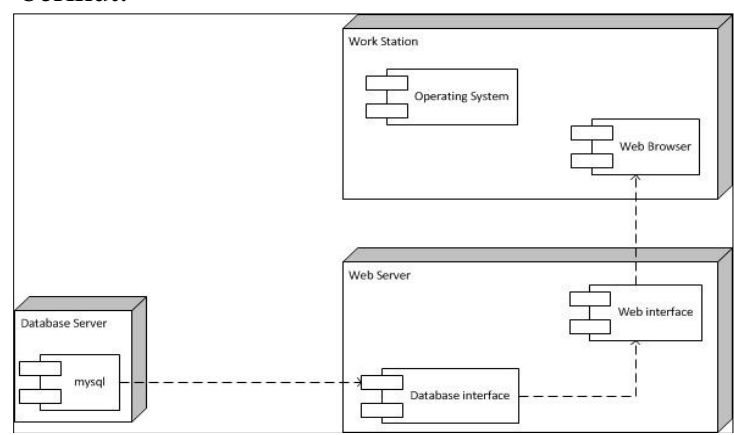

Gambar 17. Deployment Diagram

\section{Squence Diagram}

\section{Sequence Diagram Login}

Sequence Diagram Login dapat dilihat pada gambar 17 berikut:

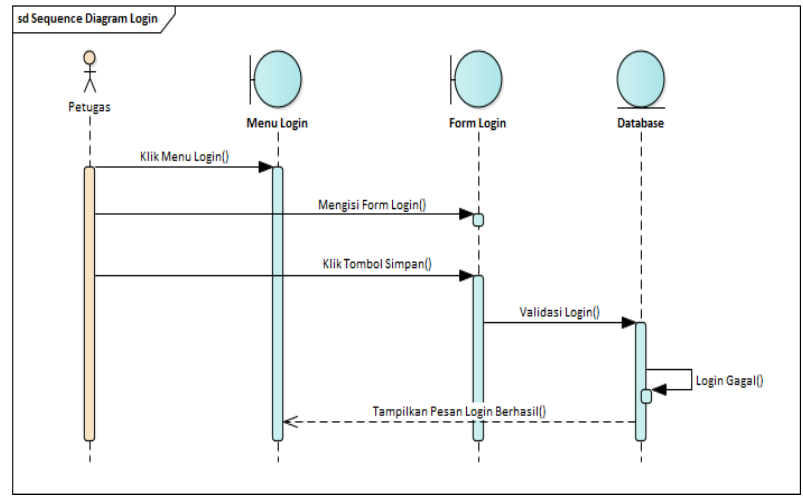

Gambar 17. Sequence Diagram Login

\section{Sequence Mengelola Data Pelatihan}

Sequence Diagram mengelola data pelatihan dapat dilihat pada gambar 18 berikut:

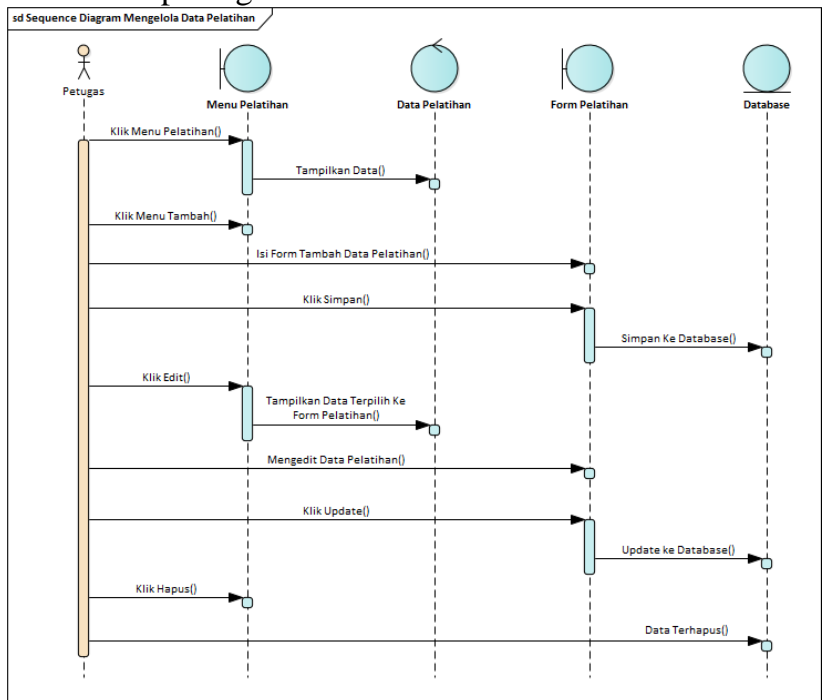

Gambar 18. Sequence Diagram Mengelola Data Pelatihan
Sequence Diagram Mengelola Data Calon Peserta dapat dilihat pada gambar 19 berikut:

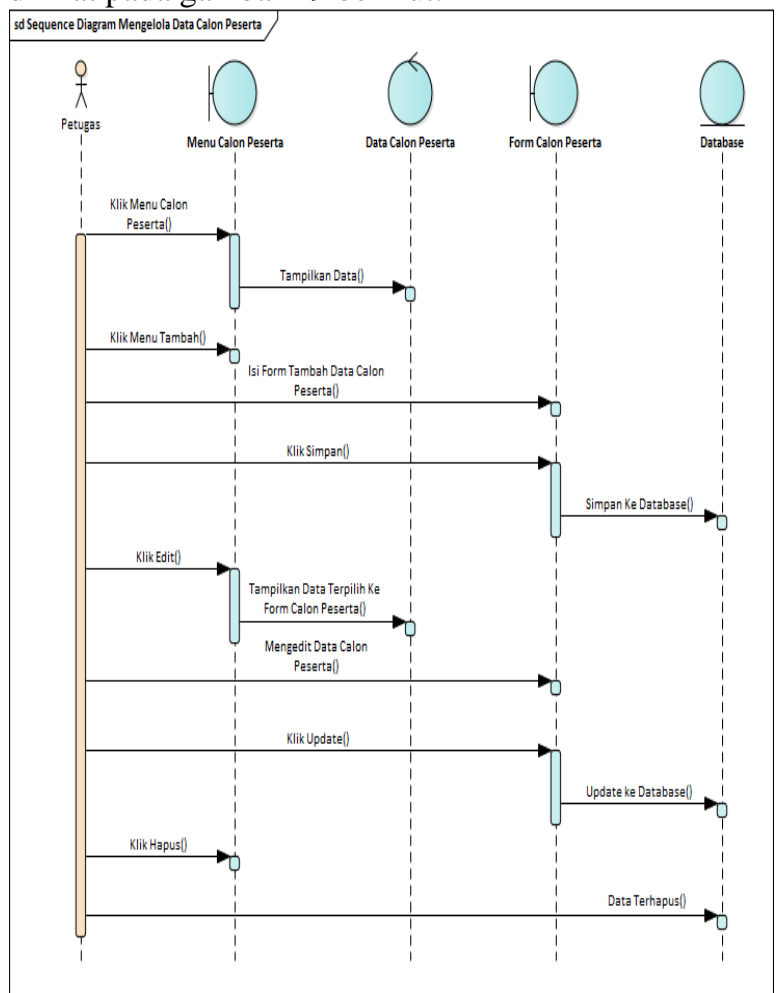

Gambar 19. Sequence Diagram Mengelola Data Calon Peserta

4. Sequence Diagram Mengelola Data Test

Sequence Diagram Mengelola Data Test data dilihat pada gambar 20 berikut:

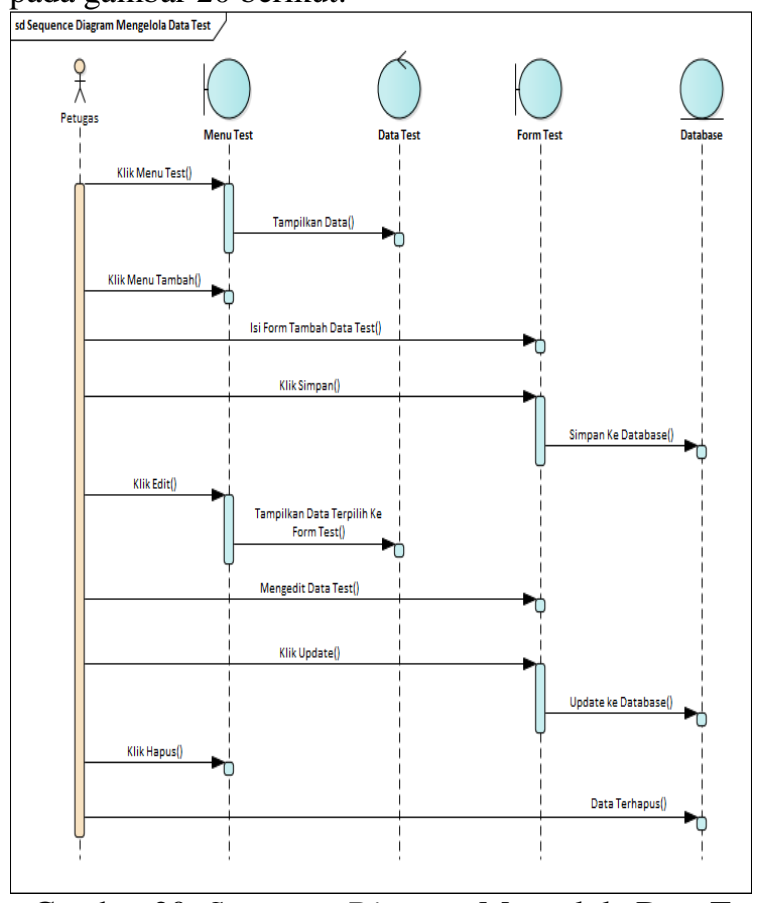

Gambar 20. Sequence Diagram Mengelola Data Test

\section{Sequence Diagram Mengelola Data Calon Peserta}


5. Sequence Diagram Mengelola Hasil Seleksi

Sequence Diagram Mengelola Hasil Seleksi dapat dilihat pada gambar 21 berikut:

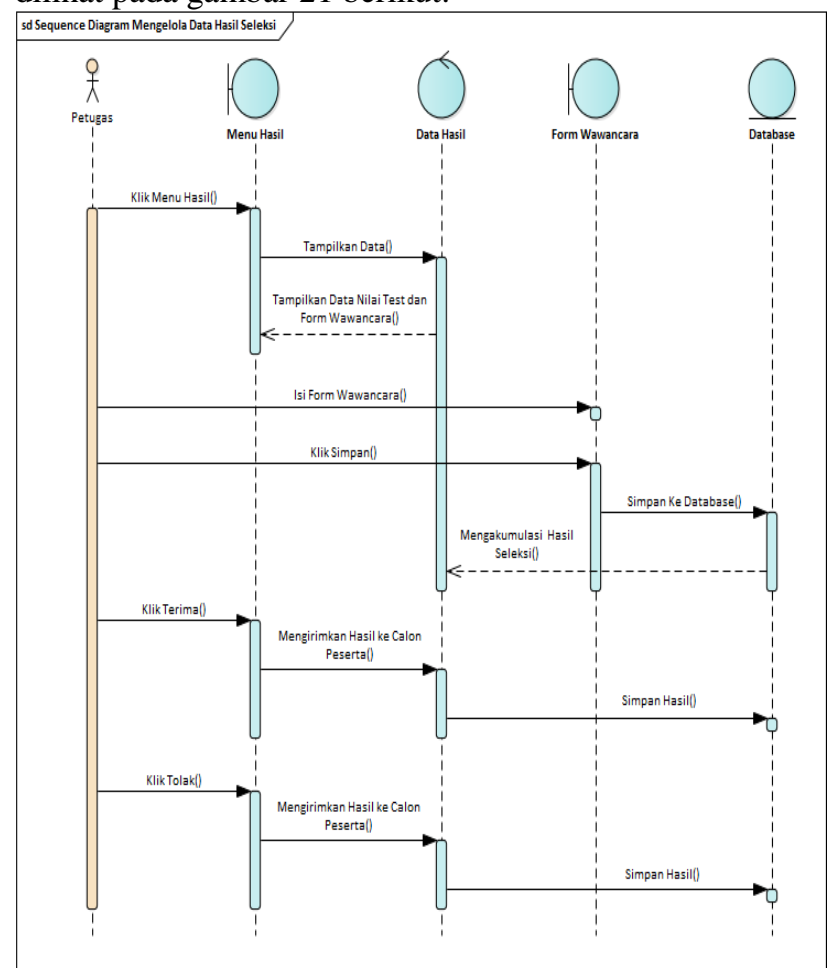

Gambar 21. Sequence Diagram Mengelola Hasil Seleksi

\section{User Interface}

Adapun Desain User Interface yang telah dibuat dalam sistem pembelian ini sebagai berikut:

a. Halaman Login Petugas

Pada halaman ini terdapat form login petugas dimana wajib menginputkan username dan password, jika meng-klik tombol login maka dapat masuk ke halaman menu Utama. Tampilan menu login dapat dilihat pada gambar 22 berikut:

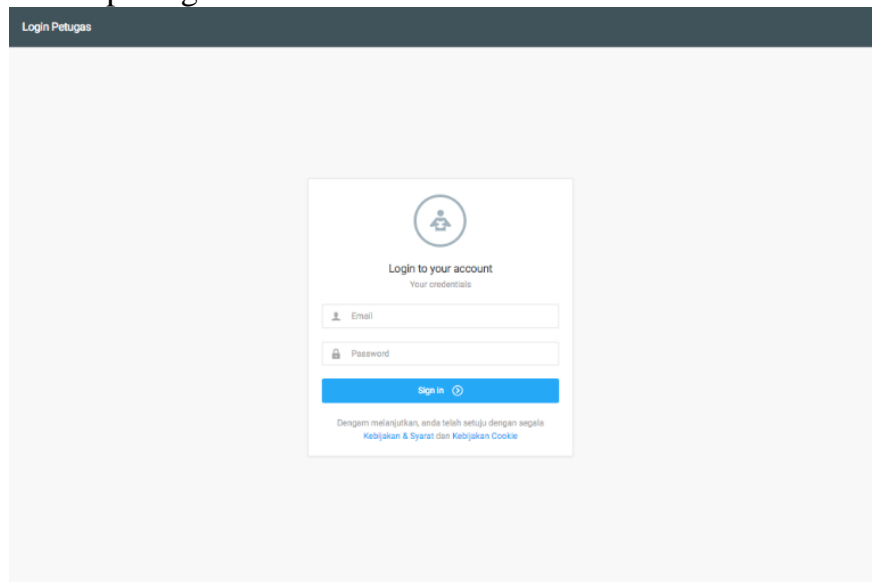

Gambar 22. Halaman Login Petugas

\section{b. Halaman Registrasi Calon Peserta}

Halaman Registrasi Calon Peserta dapat dilihat pada gambar 23 berikut:

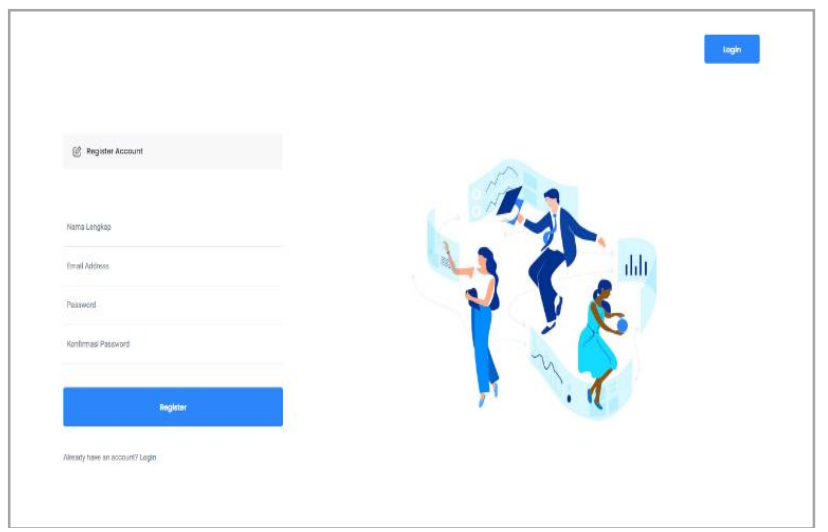

Gambar 23. Halaman Register Calon Peserta

c. Halaman Login Calon Peserta

Halaman Login Calon Peserta dapat dilihat pada gambar 24 berikut:

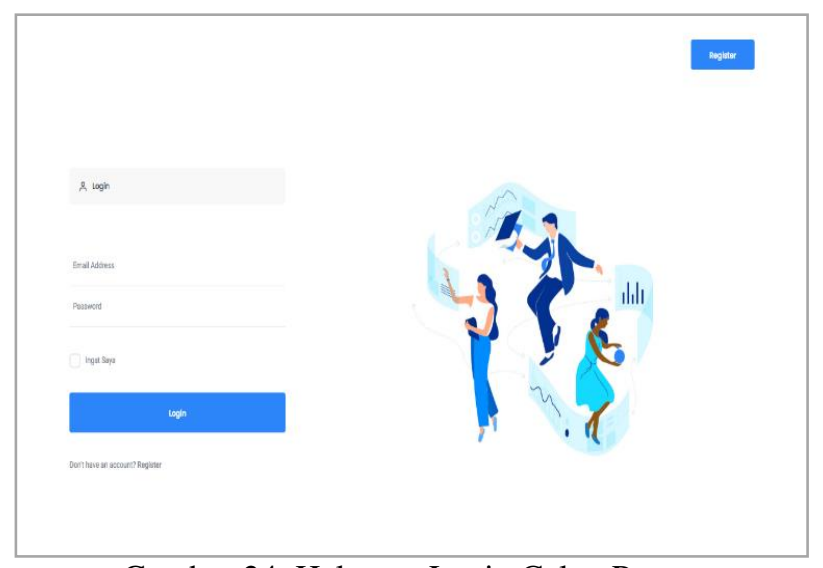

Gambar 24. Halaman Login Calon Peserta

d. Halaman Data Diri

Halaman Data Diri dapat dilihat pada gambar 25 berikut:

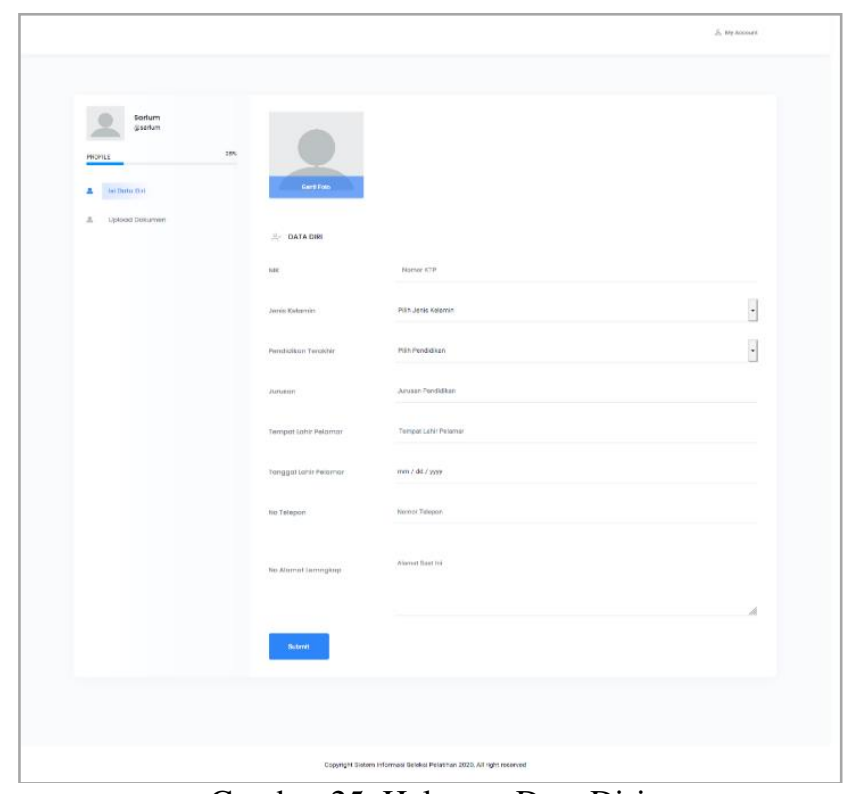

Gambar 25. Halaman Data Diri

e. Halaman Utama Calon Peserta 


\section{JURNAL SISTEM INFORMASI}

STMIK ANTAR BANGSA

Halaman Utama Calon Peserta dapat dilhat pada gambar 26 berikut:

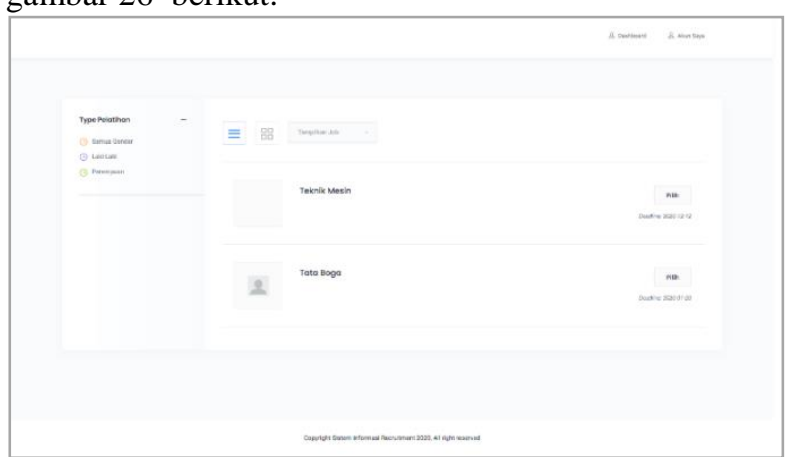

Gambar 26. Halaman Utama Calon Peserta

\section{f. Halaman Utama Petugas}

Halaman Utama Petugas dapat dilihat pada gambar 27 berikut:

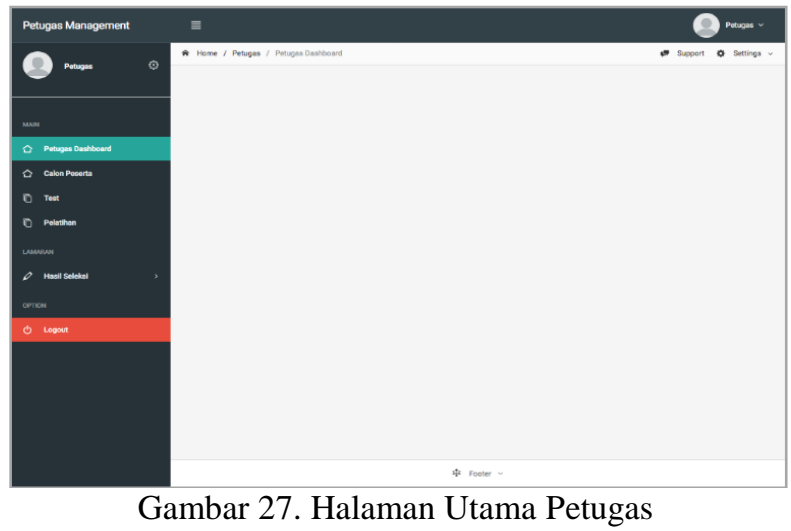

\section{g. Halaman Utama Akumulasi Hasil}

Halaman Utama Akumulasi Hasil dapat dilihat pada gambar 28 berikut:

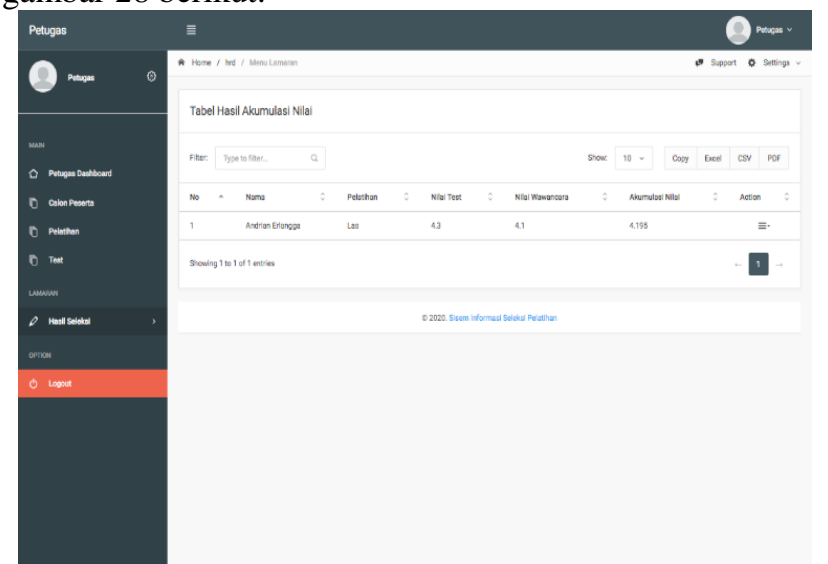

Gambar 28. Halaman Utama Akumulasi Hasil

\section{K. Kode Program}

Kode Program yang digunakan dalam pembuatan Sistem Seleksi Pelatihan Kerja adalah menggunakan bahasa pemograman HTML, CSS, PHP dan Javascript.

\section{Pengujian Program}

Pengujian program dapat dilihat dari tabel 1 sampai dengan tabel 3:

Tabel.1

Hasil Pengujian Black Box Testing Login Petugas

\begin{tabular}{|c|c|c|c|c|c|}
\hline No & $\begin{array}{l}\text { Skenario } \\
\text { Pengujian }\end{array}$ & $\begin{array}{l}\text { Test } \\
\text { Case }\end{array}$ & $\begin{array}{l}\text { Hasil } \\
\text { yang } \\
\text { diharap } \\
\text { kan }\end{array}$ & $\begin{array}{l}\text { Hasil } \\
\text { Peng } \\
\text { ujian }\end{array}$ & $\begin{array}{l}\text { Kesim } \\
\text { pulan }\end{array}$ \\
\hline 1 & $\begin{array}{l}\text { Mengoson } \\
\text { gkan } \\
\text { semua } \\
\text { isian data } \\
\text { registrasi, } \\
\text { kemudian } \\
\text { klik } \\
\text { tombol } \\
\text { "Login" }\end{array}$ & $\begin{array}{l}\text { Email: } \\
\text { (koson } \\
\text { g) } \\
\text { Passwo } \\
\text { rd: } \\
\text { (koson } \\
\text { g) }\end{array}$ & $\begin{array}{l}\text { Sistem } \\
\text { akan } \\
\text { menolak } \\
\text { akses } \\
\text { dengan } \\
\text { menampi } \\
\text { lkan } \\
\text { pesan } \\
\text { "data } \\
\text { login } \\
\text { tidak } \\
\text { boleh } \\
\text { kosong" }\end{array}$ & $\begin{array}{l}\text { Ses } \\
\text { uai } \\
\text { har } \\
\text { apa } \\
\mathrm{n}\end{array}$ & Valid \\
\hline 2 & $\begin{array}{l}\text { Mengisi } \\
\text { nama dan } \\
\text { username, } \\
\text { email dan } \\
\text { password } \\
\text { kosong, } \\
\text { kemudian } \\
\text { klik } \\
\text { tombol } \\
\text { "Login" }\end{array}$ & $\begin{array}{l}\text { Email: } \\
\text { (koson } \\
\text { g) } \\
\text { Passwo } \\
\text { rd: } \\
\text { (koson } \\
\text { g) }\end{array}$ & $\begin{array}{l}\text { Sistem } \\
\text { akan } \\
\text { menola } \\
\text { k akses } \\
\text { dengan } \\
\text { menam } \\
\text { pilkan } \\
\text { pesan } \\
\text { "data } \\
\text { login } \\
\text { belum } \\
\text { lengka } \\
\text { p" }\end{array}$ & $\begin{array}{l}\text { Ses } \\
\text { uai } \\
\text { har } \\
\text { apa } \\
\text { n }\end{array}$ & Valid \\
\hline 3 & $\begin{array}{l}\text { Mengisi } \\
\text { nama, } \\
\text { username, } \\
\text { email dan } \\
\text { password } \\
\text { isi, } \\
\text { kemudian } \\
\text { klik } \\
\text { tombol } \\
\text { "Login" }\end{array}$ & $\begin{array}{l}\text { Email: } \\
\text { (isi) } \\
\text { Passwo } \\
\text { rd: (isi) }\end{array}$ & $\begin{array}{l}\text { Sistem } \\
\text { menerim } \\
\text { a data } \\
\text { registrasi } \\
\text { dan } \\
\text { sistem } \\
\text { menampi } \\
\text { lkan } \\
\text { halaman } \\
\text { login } \\
\text { petugas }\end{array}$ & $\begin{array}{l}\text { Sesua } \\
\mathrm{i} \\
\text { harap } \\
\text { an }\end{array}$ & Valid \\
\hline
\end{tabular}

Tabel.2

Hasil Pengujian Black Box Testing Registrasi Calon Peserta 


\begin{tabular}{|c|c|c|c|c|c|}
\hline No & $\begin{array}{l}\text { Skenario } \\
\text { Pengujian }\end{array}$ & $\begin{array}{l}\text { Test } \\
\text { Case }\end{array}$ & $\begin{array}{l}\text { Hasil } \\
\text { yang } \\
\text { diharap } \\
\text { kan }\end{array}$ & $\begin{array}{l}\text { Hasil } \\
\text { Peng } \\
\text { ujian }\end{array}$ & $\begin{array}{l}\text { Kesim } \\
\text { pulan }\end{array}$ \\
\hline 1 & $\begin{array}{l}\text { Mengoson } \\
\text { gkan } \\
\text { semua } \\
\text { isian data } \\
\text { registrasi, } \\
\text { kemudian } \\
\text { klik } \\
\text { tombol } \\
\text { "Registrasi } \\
\text { " }\end{array}$ & $\begin{array}{l}\text { Nama: } \\
\text { (koson } \\
\text { g) } \\
\text { Email: } \\
\text { (koson } \\
\text { g) } \\
\text { Passwo } \\
\text { rd: } \\
\text { (koson } \\
\text { g) }\end{array}$ & $\begin{array}{l}\text { Sistem } \\
\text { akan } \\
\text { menolak } \\
\text { akses } \\
\text { dengan } \\
\text { menampi } \\
\text { lkan } \\
\text { pesan } \\
\text { "data } \\
\text { registrasi } \\
\text { tidak } \\
\text { boleh } \\
\text { kosong" }\end{array}$ & $\begin{array}{l}\text { Ses } \\
\text { uai } \\
\text { har } \\
\text { apa } \\
\text { n }\end{array}$ & Valid \\
\hline 2 & $\begin{array}{l}\text { Mengisi } \\
\text { nama dan } \\
\text { username, } \\
\text { email dan } \\
\text { password } \\
\text { kosong, } \\
\text { kemudian } \\
\text { klik } \\
\text { tombol } \\
\text { "Registrasi } \\
\text { " }\end{array}$ & $\begin{array}{l}\text { Nama: } \\
\text { (isi) } \\
\text { Email: } \\
\text { (koson } \\
\text { g) } \\
\text { Passwo } \\
\text { rd: } \\
\text { (koson } \\
\text { g) }\end{array}$ & $\begin{array}{l}\text { Sistem } \\
\text { akan } \\
\text { menola } \\
\text { k akses } \\
\text { dengan } \\
\text { menam } \\
\text { pilkan } \\
\text { pesan } \\
\text { "data } \\
\text { registra } \\
\text { si } \\
\text { belum } \\
\text { lengka } \\
\text { p" }\end{array}$ & $\begin{array}{l}\text { Ses } \\
\text { uai } \\
\text { har } \\
\text { apa } \\
\text { n }\end{array}$ & Valid \\
\hline 3 & $\begin{array}{l}\text { Mengisi } \\
\text { nama, } \\
\text { username, } \\
\text { email dan } \\
\text { password } \\
\text { isi, } \\
\text { kemudian } \\
\text { klik } \\
\text { tombol } \\
\text { "Registrasi } \\
\text { " }\end{array}$ & $\begin{array}{l}\text { Nama: } \\
\text { (isi) } \\
\text { Email: } \\
\text { (isi) } \\
\text { Passwo } \\
\text { rd: (isi) }\end{array}$ & $\begin{array}{l}\text { Sistem } \\
\text { menerim } \\
\text { a data } \\
\text { registrasi } \\
\text { dan } \\
\text { sistem } \\
\text { menampi } \\
\text { lkan } \\
\text { halaman } \\
\text { login } \\
\text { Calon } \\
\text { Peserta }\end{array}$ & $\begin{array}{l}\text { Sesua } \\
\mathrm{i} \\
\text { harap } \\
\text { an }\end{array}$ & Valid \\
\hline
\end{tabular}

Tabel.3

Hasil Pengujian Black Box Testing Login Calon

Peserta

\begin{tabular}{|c|c|c|c|c|c|}
\hline No & $\begin{array}{l}\text { Skenario } \\
\text { Pengujian }\end{array}$ & $\begin{array}{l}\text { Test } \\
\text { Case }\end{array}$ & $\begin{array}{l}\text { Hasil } \\
\text { yang } \\
\text { diharap } \\
\text { kan }\end{array}$ & $\begin{array}{l}\text { Hasil } \\
\text { Peng } \\
\text { ujian }\end{array}$ & $\begin{array}{l}\text { Kesim } \\
\text { pulan }\end{array}$ \\
\hline 1 & $\begin{array}{l}\text { Mengoson } \\
\text { gkan } \\
\text { semua } \\
\text { isian data } \\
\text { registrasi, } \\
\text { kemudian } \\
\text { klik }\end{array}$ & $\begin{array}{l}\text { Email: } \\
\text { (koson } \\
\text { g) } \\
\text { Passwo } \\
\text { rd: } \\
\text { (koson } \\
\text { g) }\end{array}$ & $\begin{array}{l}\text { Sistem } \\
\text { akan } \\
\text { menolak } \\
\text { akses } \\
\text { dengan } \\
\text { menampi } \\
\text { lkan } \\
\text { pesan }\end{array}$ & $\begin{array}{l}\text { Ses } \\
\text { uai } \\
\text { har } \\
\text { apa } \\
\text { n }\end{array}$ & Valid \\
\hline
\end{tabular}

\begin{tabular}{|c|c|c|c|c|c|}
\hline No & $\begin{array}{l}\text { Skenario } \\
\text { Pengujian }\end{array}$ & $\begin{array}{l}\text { Test } \\
\text { Case }\end{array}$ & $\begin{array}{l}\text { Hasil } \\
\text { yang } \\
\text { diharap } \\
\text { kan }\end{array}$ & $\begin{array}{l}\text { Hasil } \\
\text { Peng } \\
\text { ujian }\end{array}$ & $\begin{array}{l}\text { Kesim } \\
\text { pulan }\end{array}$ \\
\hline & $\begin{array}{l}\text { tombol } \\
\text { "Login" }\end{array}$ & & $\begin{array}{l}\text { "data } \\
\text { login } \\
\text { tidak } \\
\text { boleh } \\
\text { kosong" }\end{array}$ & & \\
\hline 2 & $\begin{array}{l}\text { Mengisi } \\
\text { nama dan } \\
\text { username, } \\
\text { email dan } \\
\text { password } \\
\text { kosong, } \\
\text { kemudian } \\
\text { klik } \\
\text { tombol } \\
\text { "Login" }\end{array}$ & $\begin{array}{l}\text { Email: } \\
\text { (koson } \\
\text { g) } \\
\text { Passwo } \\
\text { rd: (isi) }\end{array}$ & $\begin{array}{l}\text { Sistem } \\
\text { akan } \\
\text { menola } \\
\text { k akses } \\
\text { dengan } \\
\text { menam } \\
\text { pilkan } \\
\text { pesan } \\
\text { "data } \\
\text { login } \\
\text { belum } \\
\text { lengka } \\
\text { p" }\end{array}$ & $\begin{array}{l}\text { Ses } \\
\text { uai } \\
\text { har } \\
\text { apa } \\
\mathrm{n}\end{array}$ & Valid \\
\hline 3 & $\begin{array}{l}\text { Mengisi } \\
\text { nama, } \\
\text { username, } \\
\text { email dan } \\
\text { password } \\
\text { isi, } \\
\text { kemudian } \\
\text { klik } \\
\text { tombol } \\
\text { "Login" }\end{array}$ & $\begin{array}{l}\text { Email: } \\
\text { (isi) } \\
\text { Passwo } \\
\text { rd: (isi) }\end{array}$ & $\begin{array}{l}\text { Sistem } \\
\text { menerim } \\
\text { a data } \\
\text { login dan } \\
\text { sistem } \\
\text { menampi } \\
\text { lkan } \\
\text { halaman } \\
\text { login } \\
\text { Calon } \\
\text { Peserta }\end{array}$ & $\begin{array}{l}\text { Sesua } \\
\text { i } \\
\text { harap } \\
\text { an }\end{array}$ & Valid \\
\hline
\end{tabular}

\section{KESIMPULAN}

\section{A. Kesimpulan}

Setelah penulis melakukan riset, agar memahami dan berusaha memecahkan permasalahan yang ada didalam sistem seleksi peserta pelatihan, maka dari uraian bab-bab sebelumnya dapat diambil kesimpulan sebagai berikut: Dengan menerapkan sistem informasi seleksi calon peserta maka dapat meminimalisir waktu dan biaya dalam proses seleksi peserta pelatihan kerjabaru, Pemrosesan informasi lowongan seleksi lebih cepat dan efisien dan Membantu mendapatkan calon peserta terbaik yang sesuai dengan posisi pelatihan yang dibutuhkan. 


\section{REFERENSI}

[1] T. A. Siswanto, "Pengaruh Penerapan Teknologi Informasi Terhadap Kebutuhan Diklat Guru Smk Bidang Bisnis Dan Pariwisata," Sekretari, vol. 1, no. 2, p. 36, 2017.

[2] A. Nisa, "Pengaruh Kualitas Informasi Dan Kualitas Sistem Informasi Terhadap Kepuasan Serta Kinerja Pengguna Sistem Informasi," Ef. J. Bisnis dan Ekon., vol. 6, no. 1, pp. 57-59, 2015.

[3] Marlina., "Rancang Bangun Sistem Informasi Penjualan Barang Secara Tunai," J. Komput. Dan Inform., vol. XX, no. 2, pp. 129-135, 2018

[4] R. I. Desanti and A. E. Widjaja, "Aplikasi Perekrutan dan Penilaian Karyawan Berbasis Web pada PT. XYZ," J. Ultim. InfoSys, vol. 8, no. 2, pp. 74-80, 2018.

[5] K. Dwi Nanda and A. Prasetya, "Efektifitas Penerapan Metode Rekrutmen Online (E- Recruitment) (Studi Pada PT Industri Kereta Api (INKA) - Jawa Timur)," J. Adm. Bisnis, vol. 53, no. 1, pp. 96-104, 2017.

[6] Sugiyono, Metode Penelitian Kuantitatif dan Kualitatif. Bandung: Penerbit Alfabet, 2009.

[7] R. A. Sukamto and M. Shalahuddin, Perangkat Lunak dan Berorientasi Objek. Bandung: Bandung:Infomatika, 2016.

[8] Indrajani., Database Desaign. PT. Elex Media Komputindo., 2015.

[9] O. Pahlevi, A. Mulyani, and M. Khoir, "Sistem Informasi Inventori Barang Menggunakan Metode Object Oriented Di Pt. Livaza Teknologi Indonesia Jakarta," J. PROSISKO, vol. 5, no. 1, 2018.

[10] A. Herliana and P. M. Rasyid, "Sistem Informasi Monitoring Pengembangan Software pada Tahap Development Berbasis Web," J. Inform., vol. 3, no. 1, pp. 41-50, 2016.

[11] A. Puspita, M. Fahmi, and Y. Yuningsih, "Perancangan Dan Pembuatan Aplikasi E-Learning Menggunakan Model Waterfall Pada Sekolah Menengah Atas," J. Ris. Inform., vol. 1, no. 4, pp. 173-180, 2019.

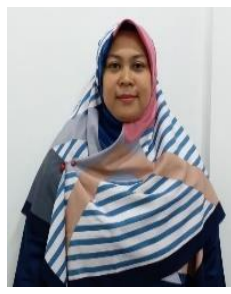

Yuyun Yuningsih, M.Kom adalah dosen pada program studi Sistem Informasi STMIK Nusa Mandiri. Lulus Program Strata Satu (S1) Program Studi Sistem Informasi STMIK Nusa Mandiri pada tahun 2013. dari pendidikan Lulus Pasca Sarjana STMIK Nusa Mandiri pada tahun 2015.

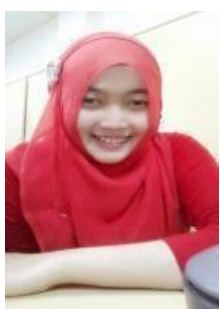

Ari Puspita,M.Kom. Tahun 2011 lulus dari Program Strata Satu (S1) Program Studi Sistem Informasi STMIK Nusa Mandiri. Tahun 2015 Lulus dari Magister Ilmu Komputer Program Pascasarjana STMIK Nusa Mandiri. 